\title{
Potential theranostics of circulating tumor cells and tumor-derived exosomes application in colorectal cancer
}

Somayeh Vafaei ${ }^{1,2,3}$, Raheleh Roudi $^{1}, Z^{2}$ hhra Madjd ${ }^{1,2^{*}}$, Amir Reza Aref ${ }^{4}$ and Marzieh Ebrahimi ${ }^{3^{*}}$

\begin{abstract}
Background: At the present time, colorectal cancer (CRC) is still known as a disease with a high mortality rate. Theranostics are flawless scenarios that link diagnosis with therapy, including precision medicine as a critical platform that relies on the development of biomarkers particularly "liquid biopsy". Circulating tumor cells (CTCS) and tumor-derived exosomes (TDEs) in a liquid biopsy approach are of substantial importance in comparison with traditional ones, which cannot generally be performed to determine the dynamics of the tumor due to its wide restriction of range. Thus, recent attempts has shifted towards minimally noninvasive methods.

Main text: CTCs and TDEs, as significant signals emitted from the tumor microenvironment, which are also detectable in the blood, prove themselves to be promising novel biomarkers for cancer diagnosis, prognosis, and treatment response prediction. The therapeutic potential of them is still limited, and studies are at its infancy. One of the major challenges for the implementation of CTCs and TDEs which are new trends in translational medicine is the development of isolation and characterization; a standardizable approach. This review highlights and discusses the current challenges to find the bio fluids application in CRC early detection and clinical management.
\end{abstract}

Conclusion: Taken together, CTCs and TDEs as silent drivers of metastasis can serve in the management of cancer patient treatment and it is of the upmost importance to expand our insight into this subject. However, due to the limited data available from clinical trials, further validations are required before addressing their putative application in oncology.

Keywords: Colorectal cancer, Circulating tumor cells (CTCS), Tumor-derived exosomes (TDEs), Clinical trial,

Theranostic

\section{Background}

Colorectal cancer $(\mathrm{CRC})$ is the third leading cause of cancer-related mortality and morbidity [1] and fifty percent of patients suffering from metastasis undergo surgery [2] which creates huge obstacles in treatment and eventually

\footnotetext{
*Correspondence: majdjabari.z@iums.ac.ir; mebrahimi@royaninstitute.org

${ }^{2}$ Department of Molecular Medicine, Faculty of Advanced Technologies

in Medicine, Iran University of Medical Sciences, Tehran, Iran

${ }^{3}$ Department of Stem Cells and Developmental Biology, Cell Science

Research Center, Royan Institute for Stem Cell Biology and Technology, ACECR, Tehran, Iran

Full list of author information is available at the end of the article
}

leads to patient death. Unfortunately, primary tumor resection appears not able to evacuate seeded malignant growth cells, and guides dormant cancer cells to induce metastatic growth leading to recurrence by circulating tumor cells (CTCs) and tumor-derived exosomes (TDE) in some cases [3]. Traditional biomarkers (CEA, CA19-9 and FOBT), as well as colon/sigmoidoscopy play an unsatisfactory specificity roles in colorectal screening [4]. Since the demerits of these various CRC screening tests are considerable [5]; shifting to repeatable noninvasive methods such as liquid biopsy attracted much attention $[6,7]$. 
CTCs and TDEs are liquid biopsy tools which can provide complementary information about the whole tumor $[8,9]$. Detection of them as a source of molecular markers (DNA, RNA, miRNA and proteins) provide relevant predictive gene signatures. They can be isolated from body fluids to elucidate patient's clinical guidance and mediated tumor signatures $[10,11]$. They are important in diagnostic, prognostic and cancer staging and has profitable usage in the estimation of relapse risk, therapeutic targets identification, intervention for stratification, sequential and continuous checking of treatments, determination of predictive information, and minimal residual disease follow up [12, 13]. Standardization of integrated pre/post analytical workflows of sample handling (isolation and characterization) must be greatly considered as priorities in increasing patient survival due to accurate therapy decision making [14]. The current review summarizes clinical translation, isolation methods, and crosstalk of CTCs and TDEs as a practical concept in colorectal cancer liquid biopsy.

\section{CTCs \& TDEs in CRC}

\section{Comprehensive concept and biology}

The main step in cancer progression is detachment, invasion of cancer cells and extravasation in order to metastasize to survive [15]. The most important materials shed into the systemic blood to establish pre-metastatic niche in maintenance of stemness and promote immune evasion include CTCs, TDEs and even cancer stem cells (CSCs). CTCs as a valuable disease indicator [16] among thousands of tumor cells leak into circulation and can survive. This ability is due to various mechanisms attributed to it such as resistance to blood shearing forces, anoikis, immune system attack and also down regulation of $c$-myc, $\beta$-catenin and Ki-67, and over expression of CD47 [17]. An average number of CTCs in a metastatic patient is between 5 and 50 in $7.5 \mathrm{cc}$ peripheral blood, thus it is extremely low and suffers a number of challenges such as high fragility, low half-life, gain/loss of cell markers, vast range of phenotypic and genotypic heterogeneity, and plasticity [18].

On the other hand, the concept of CSCs as a small population with diverse phenotype, self-renewal ability, cellular differentiation and resistance to conventional therapies can contribute to tumor progression $[19,20]$. Self- homing CTCs have been reported as delivery vehicles for anti-cancer therapeutics. Hence, detection, enumeration and molecular characterization of CTCs and CSCs are considered to be impediment factors in cancer clinics [21].

Tumor cells shed under epithelial mesenchymal transition (EMT) or by centrosome amplification triggering or external forces [22]. In addition, the mesenchymal epithelial transition (MET), as a reverse process, establishes micro metastasis. Advancing knowledge related to dominant drivers in cancer complex interactions is critical for therapeutic scheme design [23].

CTCs may exist as single cells with a wide range of EMT phenotype or in clusters with platelets, and/or reactivated stromal cells and macrophages [24]. CTC phenotype incorporate with epithelial tumor cells as well as EMT, half-breed (epithelial/EMT), irreversible EMT cancer cells, and CSCs that is shown in Fig. 1 [25]. Platelets surround the CTCs as supporters and promote tumor cells EMT and facilitate development in the distant organs [26]. CTC numbers before and during treatment are an independent indicator of overall survival (OS) and progression-free survival (PFS), by genome, expression, protein and functional analysis [27]. CTCs from 2004 in three metastatic cancers were introduced in clinics as an independent prognostic factor of survival [21].

Additionally, extracellular vesicles (EVs) contain apoptotic bodies $(500-1000 \mathrm{~nm})$, microvesicles $(100-350 \mathrm{~nm})$, and exosomes (30-150 nm) [28]. Pan et al. in 1983, for the first time, introduced and confirmed exosomes $[29,30]$ which are vesicles secreted by various kinds of cells and include a broad repertoire of cargo such as DNAs, RNA, proteins and lipids (Fig. 1) [31]. TDEs are originated from multivesicular bodies (MVBs) and the plasma membrane fusion and release their contents to be uptaken by targets. TDEs are capable of modulate cellular activities via transferring genetic data of tumor and reflect the original cell nature. Exosomes which promote adhesion, not only play a significant role in triggering signaling pathways such as immune escape and inflammatory responses, but also act in the diagnosis, prognosis and treatment assessment [21]. Additionally, they have been engineered as vectors in cancer intervention and affect the tumor microenvironment [32]. They modulate the immune response, regulate intercellular communication, mediate tumor resistance by drug efflux, and are even introduced as potential biomarkers in various diseases $[33,34]$.

\section{General approaches in isolation and characterization}

Considering the importance of these two biomarkers in basic research and clinical translation, investigating the isolation, enrichment, molecular and bioinformatics analysis of them as opposed to a complex biological background is crucial [35]. In the past, scientific proof on CTCs via RT-PCR and immunocytochemistry based on epithelial-specific antibodies gave false positive results [36].

CTC detections include five technical indicators: capturing rate efficiency or recovery, purity in the enriched sample, CTC concentration limitation in the blood, 


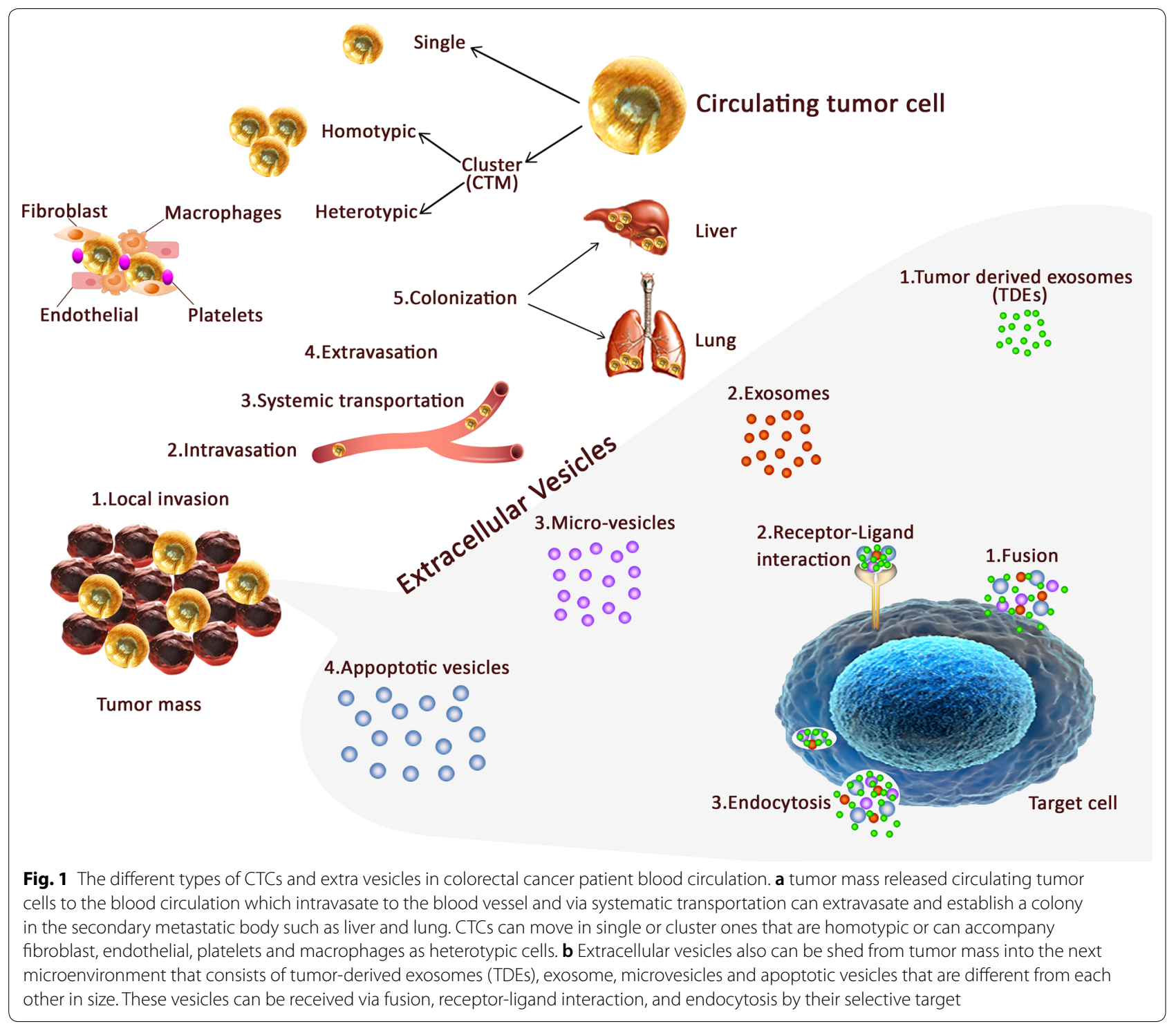

throughput and biocompatibility [37]. Three general mechanisms of CTC enrichment have been developed based on the importance of isolation approach namely: (1) biological, (2) physical and (3) functional, which have been illustrated in Table 1. (1) Immuno/magnetic affinity surface/intra cellular marker based on (peptide/aptamer/ antibodies) affinity [38]: (1-A) In positive selection/ capture, CTCs are directly isolated. The first and gold standard systems worked based on EpCAM named CellSearch $^{\mathrm{TM}}$ as the only FDA platform in which labeling with an avidin-biotin anti-EpCAM-ferrofluid complex was employed; [39] this method can also be used in vivo assay [40]. (1-B) negative selection can be helpful for avoiding selection bias marker based on tumor heterogeneity via depletion of abundant leucocytes through removal CD45 and other antigens. (1-C) combination of both selection such as Liquid Biopsy platform [41].

(2) Physical/direct enrichment of CTCs (e.g. size and deformability, gradient density and di-electrophoresis) are the second criteria that can be used to enrich cancer cells from blood cells positively and/or negatively. CTCs are bigger than $12 \mu \mathrm{m}$ in comparison with Lymphocytes and neutrophils which are lower than $12 \mu \mathrm{m}$ [42].

(3) Functional measurement exploit CTC cellular activity, enrichment and separation, namely epithelial immunospot secreted tumor-marker proteins, and have been reported in several cancers [43].

Microfluidics has opened a new window in general methods via hydrodynamics/inertial focusing/spiral to separate CTCs from other blood cells passively. Utilizing 
Table 1 Enrichment/isolation approaches of CTCs based on the inherent characteristics

\begin{tabular}{|c|c|}
\hline Total approach & Methods/kits \\
\hline \multicolumn{2}{|l|}{ Biological (Immuno-affinity) } \\
\hline Negative selection & $\begin{array}{l}\text { Rosettesep [50]/Easysep [51]/Magnetic-activated cell sorting (MACS) [52]/Fluorescence-activated cell sorting (FACS) [53]/ } \\
\text { Dynal Invitrogen [54]/CTC-iChip [55]/Ephesia [56]/GEDI [57]/QMS [58] }\end{array}$ \\
\hline Positive selection & $\begin{array}{l}\text { Cell search [39]/Magnetic-activated cell sorting (MACS) [52]/Fluorescence-activated cell sorting (FACS) [53]/Epic system } \\
\text { [59] Magsweeper [60]/Rosettesep/Easysep/Cytoquest/Adnatest [61]/GILUPI Nanodetector [62]/Liquid Biopsy (Cynve- } \\
\text { nio) [45]/Dynal Invitrogen }\end{array}$ \\
\hline \multicolumn{2}{|l|}{ Physical } \\
\hline Size & $\begin{array}{l}\text { Label-free/Spiral/Nortex/Microfiltration/Vycap/IsoFlux (Fluxion) [62]/Rare cell Devices Isolation by SizE of Tumor/Tropho- } \\
\text { blastic Cells (ISET) [63]/DEPArray [64]/(Silicon Biosystems)/ApoStream (ApoCell) [65]/Clear cell Parsortix [66]/Flexible } \\
\text { micro spring array (FMSA) [67]/fiber-optic array scanning technology (FAST) [68]/Metacell [69]/Resettable Cell Trap/ } \\
\text { CellSieve/FaCTCheckr/ScreenCell/ClearCell FX [70] }\end{array}$ \\
\hline Gradient density & OncoQuick (Grenier Bio-One) Ficoll-Paque [71]/Rosettesep/CyteSealer/AccuCyte [72] \\
\hline Di-electrophoretic (DEP) & DEP-FFF/LFFF-DEP $[73,74]$ \\
\hline Functional analysis & EPISOTNita-Assay (Vitatex) [75]/Epithelial ImmunoSPOT [38]/in vivo photoacoustic (PA) flow cytometry (PAFC) [62] \\
\hline
\end{tabular}

immobilized specific CTC antibodies on microchips/ micro-posts or in a herringbone design improve cell viability and efficiency [44]. Miniaturization of the traditional laboratory instrument followed by in situ cells capturing, sorting and analyzing have attracted much attention such as CTC-chip [45], graphene oxide-go chip [46], hb-chip [47], gem chip [48].

All of these abovementioned methods require identity confirmation of the captured, associated cells with differential staining using high resolution imaging with DAPI (nucleated cells), CK (CK20, CK19, CK18, and CK8) (epithelial structural), and anti-CD45 (CTCs) as DAPI+/ $C K+/ C D 45$ - from circulating white blood cells (WBCs). The time for detection of CTCs must be done at least 7 days postoperatively and also the whole CTC operation process had a significant impact on CTC results and must be carried out quickly $[18,49]$.

TDE isolation and purification among a mixture of EVs are technically unavailable at the moment. Therefore, novel isolation methods are crucial to enrich the specific subtypes [76]. Three general approaches for exosome isolation were summarized in Table 2 based on: (1) Physical characters including size and gradient density centrifugation (DGC) and ultracentrifugation (UC) (increasing centrifugal force $\geq 100,000 g$ ) apply to progressively eradicate unwanted smaller debris and bigger subpopulations of vesicles as a gold standard [77]. Furthermore, filtration and size exclusion chromatography (SEC) were considered as an important approach in this category. $\mathrm{UC}$ is a labor intensive and time-consuming procedure that requires specialist laboratory equipment that can be combined with the other modalities such as sucrose gradient and poly ethylene glycol (PEG) to increase the yield [78].
(2) Chemical properties, samples incubated with a PEG based on their solubility and exosomes separate centrifugation or filtration [79]. Currently, several exosome precipitation kits such as ExoQuick ${ }^{\mathrm{TM}}$, Exospin and the other kits are commercially available [80].

(3) Immunoplate- and immunobead-based affinity isolation can be accompanied by performing molecular labeling of the exosome, including $C D 81, C D 9, C D 63$, TSG101, HSP 70 and Alix. Magcapture ${ }^{\mathrm{TM}}$ exosome isolation kit PS and $C D 63$ dynabeads ${ }^{\circledR}$ beads work based on this approach. An ELISA-based method was also developed for exosome detection, in support of functionalized approach via specific antibodies. Characterization of exosomes based on morphology via scanning electron microscope (SEM) and transmission electron microscopy (TEM) can be determined. Then nanoparticle tracking assay (NTA) and dynamic light scattering (DLS) verify wanted vesicle size samples. Finally, their molecular profiling can be defined through conventional ELISA, PCR and western blotting $[81,82]$.

Alternatively, microfluidic based exochips and poly dimethyl siloxane (PDMS) innovative sorting platform devices by electromagnetic and electrophoretic manipulations have been developed to isolate exosomes. This technology has many advantages such as being user friendly, with quantitative readouts, high sensitivity, is economic, fast and requires minimal sample handling [83].

\section{Molecular markers}

Colorectal cancer has two types including sporadic and hereditary, the first of the two (65\%) [95] is directly impressed by personal life-style and the second one consists of familial adenomatous polyposis $(F A P)$, due to 
Table 2 Enrichment/isolation approaches of exosomes based on the inherent characteristics

\begin{tabular}{ll}
\hline & Methods/kits \\
\hline Physical & $\begin{array}{l}\text { Ultracentrifugation [84-87]/Sucrose gradient [88]/Membrane-based filtration/Filter-based/Column-based/Chro- } \\
\text { matography [89]/Nanowire trapping [90] }\end{array}$ \\
Chemical & Exoquick [91]/Exospin/qEV [92] \\
Biological (Immuno-affinity) & Magcapture ${ }^{\mathrm{TM}}$ Exosome isolation kit [93]/Dynabeads ${ }^{\circledR} /$ Fluorescence/colorimetric [94] \\
\hline
\end{tabular}

Adenomatous polyposis coli $(A P C)$ gene mutations, and $H N P C C /$ lynch syndrome, that is caused by $M M R$ genes [96].

Colorectal CTC markers included carcinoembryonic antigen (CEA/CEACAM5, 7), EpCAM, CK19 and CK20 [97, 98]. Colon stem-like cells express CD44, CD166 (ALCAM), CD133 (Prominin-1), CD29, CD24, EPCAM, doublecortin like kinase 1 ( $D C L K 1)$, Leucine-rich repeatcontaining G protein-coupled receptor $5(\operatorname{Lgr} 5)[99,100]$. Additionally, there are some known markers in targeted therapy which have been discussed clinically including $E G F R, V E G F, I G F-I R$ the insulin-like growth factor 1 receptor (IGF-1R), interleukin-4 (IL-4) and bone morphogenetic protein 4 (BMP-4) [101].

Analysis of exosome composition indicated that they express tetraspanins, a class of membrane proteins including $C D 9, C D 63$ and $C D 81$ [102]. The other frequent exosomal proteins are EpCAM, Alix, and TSG101 [103], GTPases, cytoskeletal proteins, annexines, the heat shock proteins (Hsp70 and Hsp90) [104] and integrins $[105,106]$, of which all of the valuable biomarkers were drawn in Fig. 2.

\section{Clinical applications to manage patients}

CTCs were captured via all the aforementioned approaches that have been discussed and cultured in vivo/vitro named patient-derived xenografts (PDXs) and CTC-derived xenografts (CDXs) although the establishment of permanent CTC lines is very challengeable $[21,107]$.

In this section, clinical studies concerned with the colorectal CTCs will be mentioned; 63 trials were registered in https://clinicaltrials.gov of which 22 of them were completed and summarized in Table 3. Meta-analyses and large-scale clinical trials declare that patients with CTC number $\geq 5$ (per $7.5 \mathrm{ml}$ ) were classified as being in the aggressive stage IV and would develop distant metastasis. Meanwhile, CTC level $<3$ cells can also be correlated with unfavorable prognostic factor [108] with shorter median OS and PFS [109]. Thus, it can be a vital factor in cancer progression risk assessment and patients must be stratified to be treated promptly based on molecular subtypes [110, 111]. Therefore, higher numbers of CTCs are seen in patients with a greater number of metastatic sites [112]. Regardless of the metastatic site, CTC enumeration (cell-based assays) are sufficient enough as a proper cancer monitoring index whenever $C E A$ and other markers levels are not measurable [113]. It is worthy to mention that an elevated CTC number was not necessarily associated with apoptotic CTCs or CTC debris and could be used to interrogate metastatic in patients and contribute to run tumor-associated events $[114,115]$.

In another site, only five clinical trials using the key word 'colorectal exosome' were registered that none of them completed. Recently, TDEs have been introduced as promising drug delivery vehicles in targeting different organs and their selective cargo must be determined to increase therapy effectiveness. Thus, scientists are focusing on TDEs components [116] even in inducing antitumor immune responses as cancer vaccine candidates [117]. The plasma TDE cargo is enriched in immunosuppressive and immunostimulatory receptor/ligands, MHC molecules and various tumor-associated antigens (TAAs). Their content depends on cellular origin variety and carries oncogenic DNA, microRNAs, proteins and mRNAs [118] such as $\mathrm{GPC1}^{+}$, tumor suppressor-activated pathway 6 (TSAP6) [119], $\triangle N p 73$ [120], metastatic factors (TNC, MET, S100A9, S100A8), signal transduction molecules (EFNB2, JAG1, SRC, TNIK), and lipid raft associated components (PROM1, CAV1, FLOT1 and 2). Ji et al. reported Let-7a-3p, let-7f-1-3p, miR-574-5p, miR451a, miR-7641, and miR-4454 are common to all EV subtypes [121]. In addition to the detection and co-localization of protein complexes in CRC exosomes, regulation of signaling pathways such as Wnt and EGFR ligand, besides autocrine, paracrine, and juxtacrine, contribute in priming of the metastatic niche [122]. Furthermore, inhibition of exosome secretion, besides targeting CSCs, as a new therapeutic strategy, can block tumor associated secretion before chemotherapy [123, 124] and facilitate cross talk between stromal cells and tumors in cancer microenvironment [125]. 


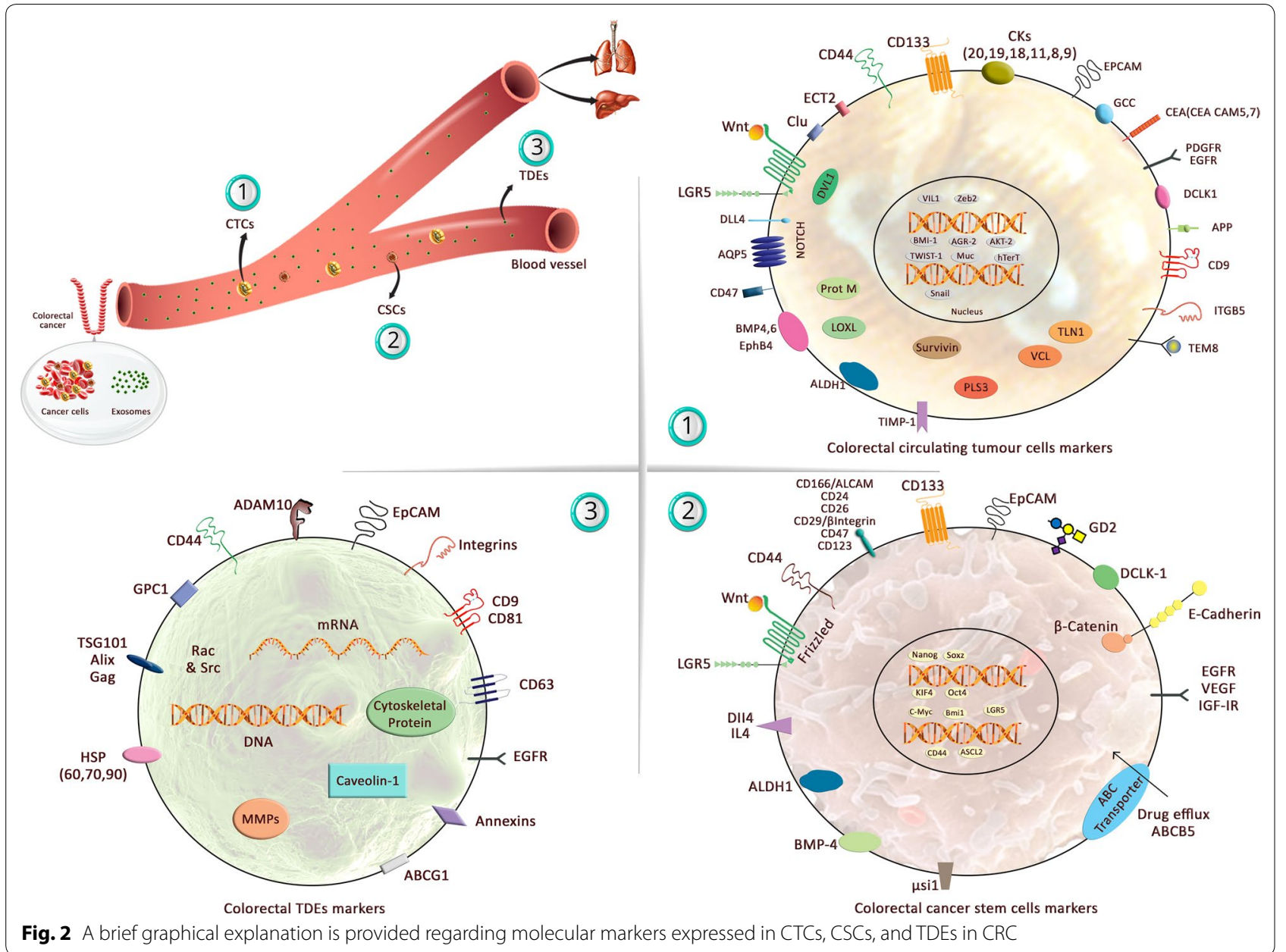

\section{Crosstalk in tumor microenvironment (TME)}

Metabolic cells reprogramming, loss of cell connection with overexpression of matrix metalloproteinases $(M M P)$, cancer cells diapedesis and its integration to define target sites contribute in metastasis cascade. Tumor microenvironment (TME) consists of CAFs, extracellular matrix (ECM), cancer- tumor-associated vasculature and inflammatory immune cells. Mediating the crosstalk between tumor and tumor-associated cells identify as a viable step in cancer development (Fig. 3) [126, 127].

Primary TDE conveys messages to the other cells which exist in TME, as well as modifying the microenvironment through their cargo. Not only does TDE play a pivotal role, but also the exosomes secreted by cancer-associated factors including CAFs, tumor-associated macrophages (TAMs), endothelium, leukocytes and progenitor cells should be considered as significant characteristics in cancer progression [128]. TDE is also important in the regulation of macrophage polarization and CAF transition [129].

The data related to the TDE roles in CRC are limited but it was approved that TDE in other cancers promotes invasiveness by regulating signaling pathway, for example, primary TDEs enhance SMAD3/ROS signaling and induce CTC survival and cell adhesion. Furthermore, the levels of TDEs markers which participated in EMT process cellular movement and cell-cell signaling in cancer patients' blood correlated with the disease stage [3]. MiRNAs encapsulated in EVs play a significant role in metastasis such as circulating exosomal microRNA-203 via inducing TAM in CRC [130], [130]. Cha et al. showed that the KRAS status of CRC have a direct influence on the type of miRNAs enriched in exosomes [131]. Conditioned media harvested from M2 macrophages which consist of derived exosomes promote CRC motility and invasion throughout IL6, Wnt5a, TNF $\alpha$ and EGF molecules [132]. 


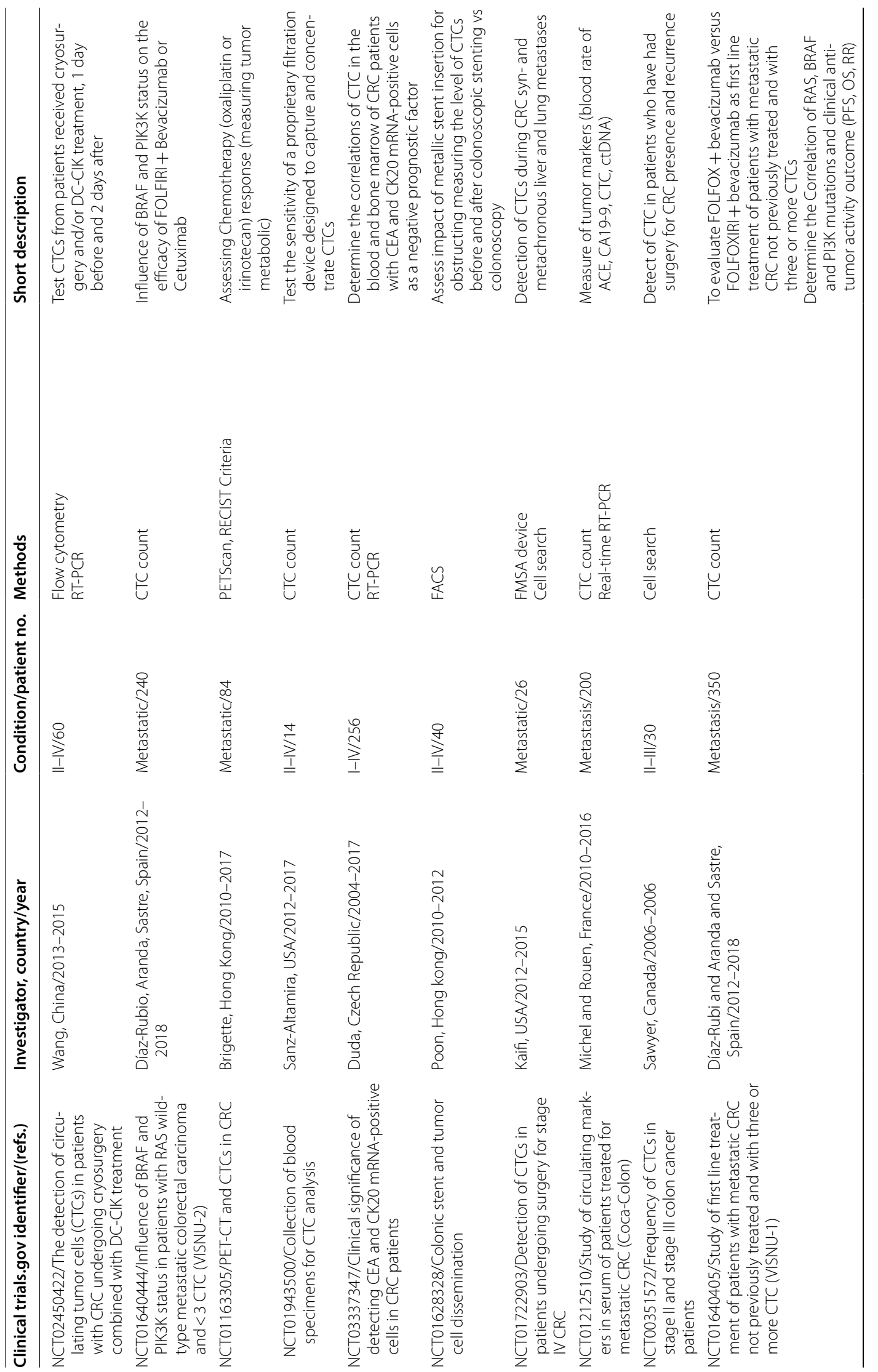




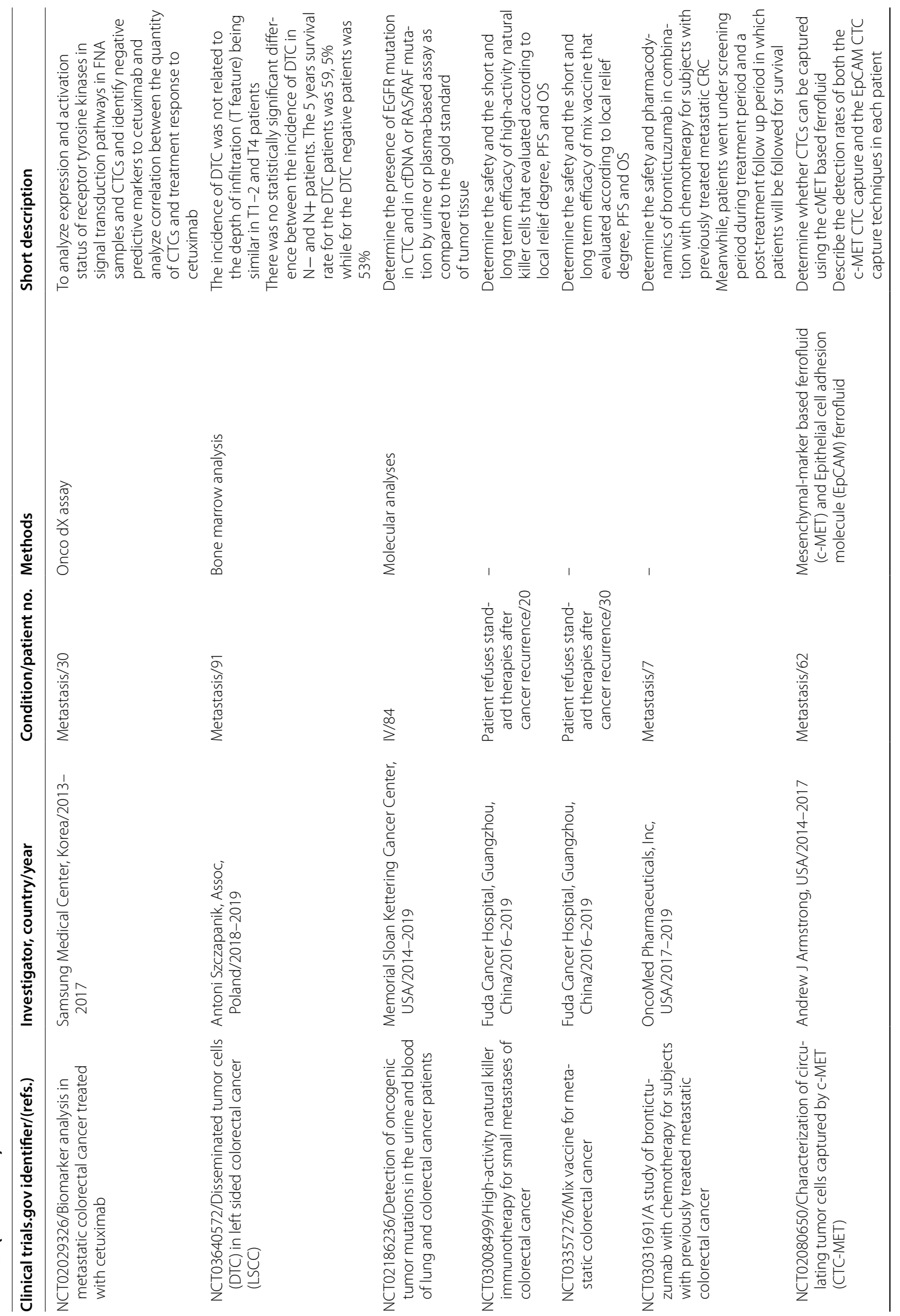




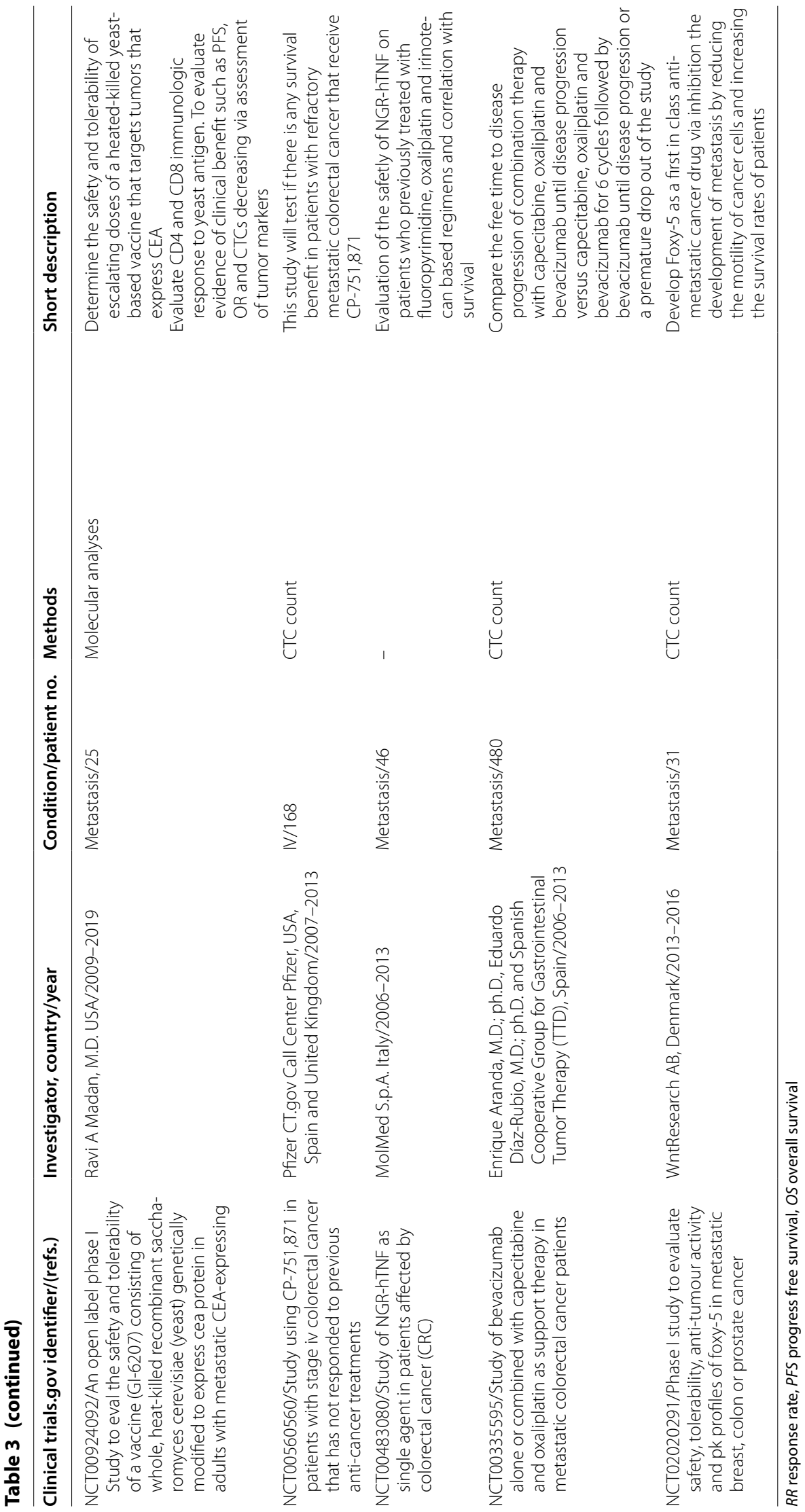


Interestingly, an acidic and hypoxic microenvironment stimulates the release of TDE and is involved in epithelial adheres junctions and cytoskeleton remodeling pathways [133]. In addition, TDEs may potentially collaborate in the dynamic regulation of the tumor fate and is considered as a valuable diagnostic non-invasive approach [34, 134].

\section{Cancer stem cells regulate tumor microenvironment via exosomes}

CSCs or "tumor-initiating cells", a rare subpopulation are capable of self-renewal and differentiate into specialized cells through symmetric division and therapeutic resistance drive tumor growth [135]. Nowadays, CSCs are investigated in various ranges of solid tumors. CSCs derived EVs contribute in tumor initiation, progression, angiogenesis, invasion and metastasis formation [136].
Tumor exosome RNAs induce the expression of interleukin- $1 \beta$ through NF- $\mathrm{kB}$ signaling leading to the survival of neutrophil sustain. Colorectal CSCs secreted $C X C L 1$ and 2 and attracted neutrophils primed via IL-1 $\beta$ to promote CRC cells tumorigenesis [137]. Moreover, exosomes may transfer mutant KRAS to recipient cells and trigger increases in $I L-8$ production, neutrophil recruitment as well as the formation of the neutrophil extracellular trap (NET), leading to the deterioration of CRC [138]. CD44v6 CSC-derived exosomes contribute to cancer development by non-cancer initiating cells to acquire the CSC phenotype [139].

EVs-derived CSCs with variable patterns of miRNA can convey their oncogenic features in order to affect cancer proliferation, progression, invasion, metastasis [140], activate angiogenesis and stimulate tumor immune escape mechanisms [141, 142] (Fig. 3).

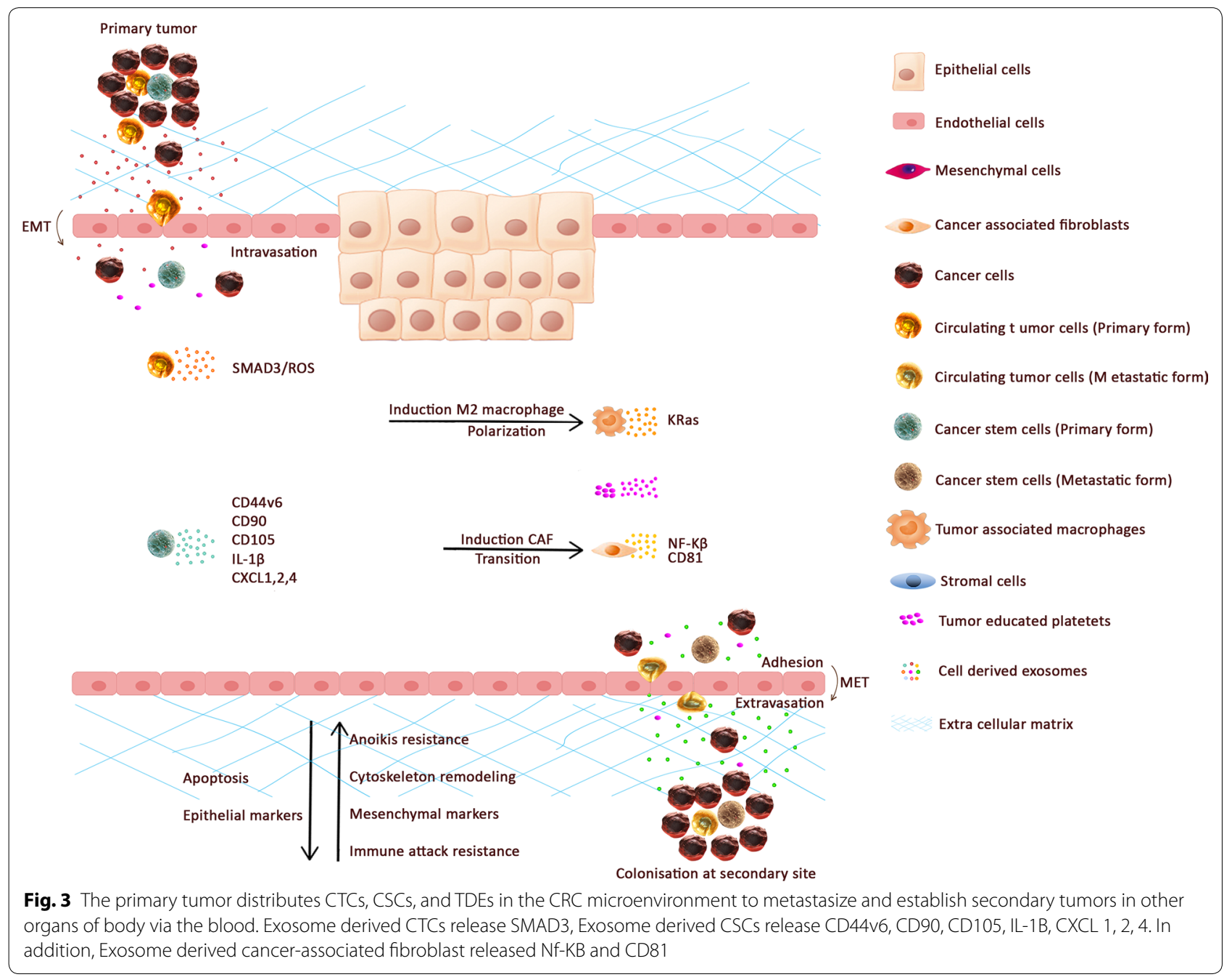




\section{Conclusion}

Tumor metastasis is still the main principle of cancer death, highlighting the importance of investigating an updating approach to control it. Cross talks among tumor cells and derived-exosomes play a significant role in a dynamic network of cancer microenvironment. Therefore, their recognition and characterization are a crucial step in accurate comprehension of molecular and cellular oncology. Tracking cancer related markers in body fluid could be helpful to measure residual disease presence, recurrence, relapse and resistance and address the needs of clinicians and patients. Liquid biopsy, including CTCs and TDEs as a noninvasive tool in the field of precision medicine, provides substantially helpful information regarding diagnosis, prognosis, predictive and pharmacodynamics.

In spite of numerous merits that can be counted for CTCs and TDEs separately or simultaneously (Fig. 4), it should be noted that the most challengeable and disadvantageous of them concern isolation and purification due to methodological restrictions (sensitivity and specificity) and standardization because heterogeneity must be resolved. For example, by inducing the apoptosis of CTCs by intervening ROS-mediated DNA damage can inhibit the CTCs metastasis along the the EGF pathway which is cleared by ingenuity exosome pathway analysis [143]. In another study, it was proved that TDEs have equivalent prognostic values to CTCs in the investigated metastatic cancers. Patients with favorable CTC counts can have further prognostic stratification using TDEs [144].

Lab on chip (LOC) technology, in order to grow awareness about the point-of-care testing in cancer was developed and because of low consumption of a sample and high compatibility with the liquid biopsy concept and personalized medicine it has been welcomed $[145,146]$. This precious dream can come true with the analysis of patient-activated social networks and systems medicine. P4 medicine that is predictive, personalized, preventive, and participatory can be helpful in this field, next to gene-panel testing due to next-generation sequencing

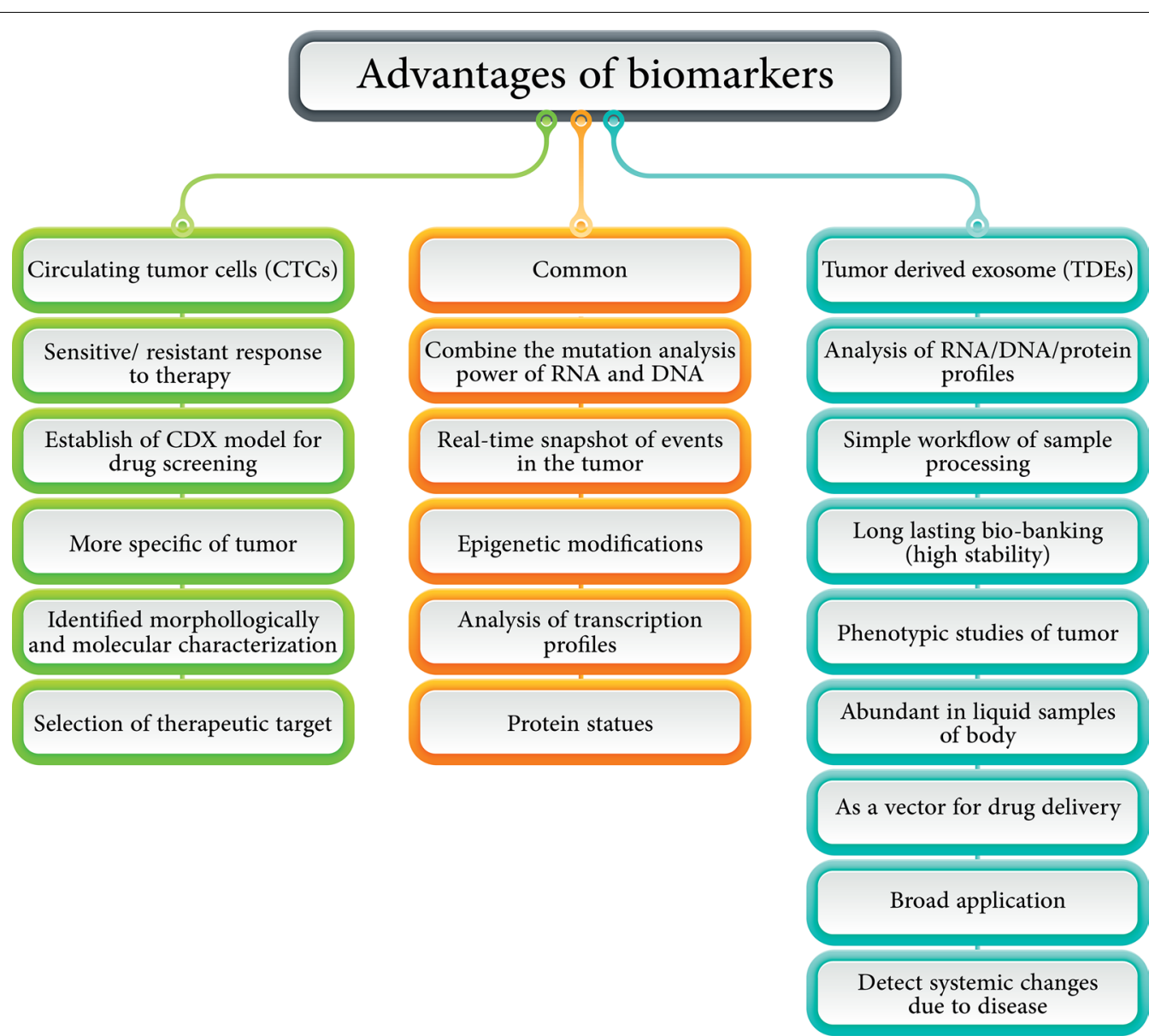

Fig. 4 Comparison of the merits of CTCS (green boxes) and TDEs (blue boxes) together. All of the common characterizations of both were drawn in the middle (orange boxes) 
(NGS) technology [147] and plays a critical role in covering the current shortcomings of liquid biopsy regarding practicality, standardization, and the result comparisons.

Despite many techniques regarding CTC exosome capturing and subgrouping are available in clinics; the need for optimization of downstream analysis is tangible. Additionally, distinguishing between CTCs with high and low metastatic status as well as between TDEs and normal status is absolutely vital. In conclusion, liquid biopsy is an expanding field in the management of CRC patient in different stages. It is highly recommended that further research be done on CTCs and TDEs alone or simultaneously until both can serve as valuable biomarkers in clinics.

\section{Abbreviations}

CRC: Colorectal cancer; CTCs: Circulating tumor cells; TDEs: Tumor-derived exosomes; CT: Computed tomography; MRI: Magnetic resonance imaging; TEPS: Tumor-educated platelets; LOC: Lab-on-a-chip; NGS: Next-generation sequencing; CSCs: Cancer stem cells; ECM: Extracellular matrix; EMT: Epithelial mesenchymal transition; MET: Mesenchymal epithelial transition; OS: Overall survival; PFS: Progression-free survival; EVs: Extracellular vesicles; MVBs: Multivesicular bodies; CK: Cytokeratin; EPCAM: Epithelial cell adhesion molecule; DGC: Gradient density centrifugation; UC: Ultracentrifugation; SEC: Size exclusion chromatography; PEG: Poly ethylene glycol; SEM: Scanning electron microscope; TEM: Transmission electron microscopy; NTA: Nanoparticle tracking assay; DLS: Dynamic light scattering; PDMS: Poly dimethyl siloxane; FAP: Familial adenomatous polyposis; APC: Adenomatous polyposis coli; DCLK1: Doublecortin like kinase 1; LGR5: Leucine-rich repeat-containing G proteincoupled receptor 5; IGF-IR: the insulin-like growth factor 1 receptor; IL-4: Interleukin-4; BMP-4: Bone morphogenetic protein 4; Hsp70: Heat shock proteins; PDXs: Patient-derived xenografts; CDXs: CTC-derived xenografts; TSAP6: Tumor suppressor-activated pathway 6; CAFs: Carcinoma-associated fibroblasts; DKK4: Dickkopf-related protein 4; TAAs: tumor-associated antigens; MMP: Matrix metalloproteinases; TME: Tumor microenvironment; Mef2c: Myocyte enhancer factor 2c; HCC: Hepatocellular carcinoma; HDGF: Hepatoma-derived growth factor; GSCs: Glioma stem cells; CLIC1: contain functionally active Cl-intracellular channel 1; NET: Neutrophil extracellular trap; EGFR: Epidermal growth factor receptor; DEP-FFF: Dielectrophoretic field-flow fractionation; VEGF: Vascular endothelial growth factor.

\section{Acknowledgements}

We are grateful of our colleague at Iran University of Medical Sciences and Royan Stem Cell Technology Company who provided insight and expertise that greatly assisted the research. Apart from, it must be declared that the authors received no specific funding for this work.

\section{Authors' contributions}

SV and ZM conceived of the presented idea. SV collected, interpreted and analyzed data and wrote the drafting of the article. ZM and ME developed, revised and approved the theory. RR and AA performed the critical revision and verified the whole concept. SV and ZM encouraged the other author to investigate and supervised the findings of this work. All authors discussed the results. All authors read and approved the final manuscript.

\section{Funding}

Not applicable.

\section{Availability of data and materials}

Data sharing is not applicable to this article as no new data were created or analyzed in this study and openly available in [repository name at http://doi. org/[doi] and reference number.

Ethics approval and consent to participate

Not applicable.

\section{Consent for publication}

All of the current study data were searched systematic and were used by reference citation and all of the authors consent to publication.

\section{Competing interests}

The authors whose names are listed certify that they have NO affiliations in any organization or entity with any financial interest and non-financial interest in the subject matter or materials discussed in this manuscript.

\section{Author details}

${ }^{1}$ Oncopathology Research Center, Iran University of Medical Sciences (IUMS), Hemmat Street (Highway), Next to Milad Tower, Tehran, Iran. ${ }^{2}$ Department of Molecular Medicine, Faculty of Advanced Technologies in Medicine, Iran University of Medical Sciences, Tehran, Iran. ${ }^{3}$ Department of Stem Cells and Developmental Biology, Cell Science Research Center, Royan Institute for Stem Cell Biology and Technology, ACECR, Tehran, Iran. ${ }^{4}$ Department of Medical Oncology, Dana-Farber Cancer Institute, Harvard Medical School, Boston, USA.

Received: 17 April 2020 Accepted: 27 June 2020

Published online: 06 July 2020

\section{References}

1. Bray F, Ferlay J, Soerjomataram I, Siegel RL, Torre LA, Jemal A. Global cancer statistics 2018: GLOBOCAN estimates of incidence and mortality worldwide for 36 cancers in 185 countries. CA Cancer J Clin. 2018;68:394-424.

2. Van Cutsem E, Cervantes A, Nordlinger B, Arnold D. Metastatic colorectal cancer: ESMO clinical practice guidelines for diagnosis, treatment and follow-up. Ann Oncol. 2014;25(Suppl 3):iii1-9.

3. Fu Q, Zhang Q, Lou Y, Yang J, Nie G, Chen Q, et al. Primary tumor-derived exosomes facilitate metastasis by regulating adhesion of circulating tumor cells via SMAD3 in liver cancer. Oncogene. 2018;37(47):6105-18.

4. Diamantis A, Magiorkinis E, Koutselini H. Fine-needle aspiration (FNA) biopsy: historical aspects. Folia Histochem Cytobiol. 2009;47(2):191-7.

5. Mousavi S, Moallem R, Hassanian SM, Sadeghzade M, Mardani R, Ferns GA, et al. Tumor-derived exosomes: potential biomarkers and therapeutic target in the treatment of colorectal cancer. J Cell Physiol. 2019;234(8):12422-32.

6. Punt CJ, Koopman M, Vermeulen L. From tumour heterogeneity to advances in precision treatment of colorectal cancer. Nat Rev Clin Oncol. 2017;14(4):235

7. Zhai Z, Yu X, Yang B, Zhang Y, Zhang L, Li X, et al. Colorectal cancer heterogeneity and targeted therapy: clinical implications, challenges and solutions for treatment resistance. Semin Cell Dev Biol. 2017;64:107-15.

8. Karachaliou N, de Las Mayo Casas C, Molina-Vila MA, Rosell R. Real-time liquid biopsies become a reality in cancer treatment. Ann Transl Med. 2015:3(3):36.

9. Brock G, Castellanos-Rizaldos E, Hu L, Coticchia C, Skog J. Liquid biopsy for cancer screening, patient stratification and monitoring. Transl Cancer Res. 2015:4(3):280-9.

10. Issa IA, Noureddine M. Colorectal cancer screening: an updated review of the available options. World J Gastroenterol. 2017;23(28):5086.

11. Lopez A, Harada K, Mizrak Kaya D, Dong X, Song S, Ajani JA. Liquid biopsies in gastrointestinal malignancies: when is the big day? Expert Rev Anticancer Ther. 2018;18(1):19-38.

12. Crowley E, Di Nicolantonio F, Loupakis F, Bardelli A. Liquid biopsy: monitoring cancer-genetics in the blood. Nat Rev Clin Oncol. 2013;10(8):472-84.

13. Alix-Panabières $C$, Pantel K. Circulating tumor cells: liquid biopsy of cancer. Clin Chem. 2013;59(1):110-8.

14. Soler A, Cayrefourca L, Mazard T, Babayan A, Lamy PJ, Assou S, et al. Autologous cell lines from circulating colon cancer cells captured from sequential liquid biopsies as model to study therapy-driven tumor changes. Sci Rep. 2018;8(1):15931.

15. van Zijl F, Krupitza G, Mikulits W. Initial steps of metastasis: cell invasion and endothelial transmigration. Mutat Res. 2011;728(1-2):23-34.

16. Ashworth TR. A case of cancer in which cells similar to those in the tumours were seen in the blood after death. Med J Aust. 1869;14:146-7. 
17. Steinert G, Scholch S, Niemietz T, Iwata N, Garcia SA, Behrens B, et al. Immune escape and survival mechanisms in circulating tumor cells of colorectal cancer. Cancer Res. 2014;74(6):1694-704

18. Kowalik A, Kowalewska M, Gozdz S. Current approaches for avoiding the limitations of circulating tumor cells detection methods-implications for diagnosis and treatment of patients with solid tumors. Transl Res. 2017;185(58-84):e15.

19. Shibue T, Weinberg RA. EMT, CSCs, and drug resistance: the mechanistic link and clinical implications. Nat Rev Clin Oncol. 2017;14(10):611-29.

20. Xu L, Shamash J, Lu Y-J. Circulating Tumor Cells: a window to understand cancer metastasis, monitor and fight against cancers. J Cancer Res Updates. 2015;4(1):13-29.

21. Zhou L, Dicker DT, Matthew E, El-Deiry WS, Alpaugh RK. Circulating tumor cells: silent predictorsof metastasis. F1000Res. 2017;6(F10000 Faculty Rev):1445

22. Satelli A, Mitra A, Brownlee Z, Xia X, Bellister S, Overman MJ, et al. Epithelial-mesenchymal transitioned circulating tumor cells capture for detecting tumor progression. Clin Cancer Res. 2015;21(4):899-906.

23. Najafi M, Goradel NH, Farhood B, Salehi E, Solhjoo S, Toolee H, et al. Tumor microenvironment: interactions and therapy. J Cell Physiol. 2019;234(5):5700-21.

24. Zhang T, Boominathan R, Foulk B, Rao C, Kemeny G, Strickler JH, et al. Development of a novel c-MET-based CTC detection platform. Mol Cancer Res. 2016;14(6):539-47.

25. Hardingham JE, Grover P, Winter M, Hewett PJ, Price TJ, Thierry B. Detection and clinical significance of circulating tumor cells in colorectal cancer-20 years of progress. Mol Med. 2015;21(Suppl 1):S25-31.

26. Zhang W, Xia W, Lv Z, Ni C, Xin Y, Yang L. Liquid biopsy for cancer: circulating tumor cells, circulating free DNA or exosomes? Cell Physiol Biochem. 2017;41(2):755-68.

27. Wang W, Wan L, Wu S, Yang J, Zhou Y, Liu F, et al. Mesenchymal marker and LGR5 expression levels in circulating tumor cells correlate with colorectal cancer prognosis. Cell Oncol. 2018;41:495-504.

28. Li P, Kaslan M, Lee SH, Yao J, Gao Z. Progress in Exosome Isolation Techniques. Theranostics. 2017;7(3):789-804.

29. Pan BT, Johnstone RM. Fate of the transferrin receptor during maturation of sheep reticulocytes in vitro: selective externalization of the receptor. Cell. 1983;33(3):967-78.

30. Harding C, Stahl P. Transferrin recycling in reticulocytes: $\mathrm{pH}$ and iron are important determinants of ligand binding and processing. Biochem Biophys Res Commun. 1983;113(2):650-8.

31. Hessvik NP, Llorente A. Current knowledge on exosome biogenesis and release. Cell Mol Life Sci. 2018;75(2):193-208.

32. He C, Zheng S, Luo Y, Wang B. Exosome theranostics: biology and translational medicine. Theranostics. 2018;8(1):237-55.

33. Wang Z, Chen JQ, Liu JL, Tian L. Exosomes in tumor microenvironment: novel transporters and biomarkers. J Transl Med. 2016;14(1):297.

34. Jia Y, Chen Y, Wang Q, Jayasinghe U, Luo X, Wei Q, et al. Exosome: emerging biomarker in breast cancer. Oncotarget. 2017:8(25):41717-33.

35. Micalizzi DS, Haber DA, Maheswaran S. Cancer metastasis through the prism of epithelial-to-mesenchymal transition in circulating tumor cells. Mol Oncol. 2017;11:770-80.

36. Goeminne JC, Guillaume T, Symann M. Pitfalls in the detection of disseminated non-hematological tumor cells. Ann Oncol. 2000;11(7):785-92.

37. Shen Z, Wu A, Chen X. Current detection technologies for circulating tumor cells. Chem Soc Rev. 2017:46(8):2038-56.

38. Zhang J, Chen K, Fan ZH. Circulating tumor cell isolation and analysis. Adv Clin Chem. 2016;75:1-31.

39. Allard WJ, Matera J, Miller MC, Repollet M, Connelly MC, Rao C, Tibbe AG, Uhr JW, Terstappen LW. Tumor cells circulate in the peripheral blood of all major carcinomas but not in healthy subjects or patients with nonmalignant diseases. Clin Cancer Res. 2004;10(20):6897-904.

40. de Wit S, van Dalum G, Lenferink AT, Tibbe AG, Hiltermann TJ, Groen $\mathrm{HJ}$, et al. The detection of $\operatorname{EpCAM}(+)$ and $\operatorname{EpCAM}(-)$ circulating tumor cells. Sci Rep. 2015:5:12270.

41. Murtaza M, Dawson SJ, Tsui DW, Gale D, Forshew T, Piskorz AM, et al. Non-invasive analysis of acquired resistance to cancer therapy by sequencing of plasma DNA. Nature. 2013;497(7447):108-12.

42. Hao SJ, Wan Y, Xia YQ, Zou X, Zheng SY. Size-based separation methods of circulating tumor cells. Adv Drug Deliv Rev. 2018;125:3-20.
43. Cayrefourcq L, De Roeck A, Garcia C, Stoebner PE, Fichel F, Garima F, et al. S100-EPISPOT: a new tool to detect viable circulating melanoma cells. Cells. 2019;8(7):755.

44. Goedecke N, Bollhalder M, Bernet R, Silvan U, Snedeker J. Easy and accurate mechano-profiling on micropost arrays. J Vis Exp. 2015;105:e53350.

45. Winer-Jones JP, Vahidi B, Arquilevich N, Fang C, Ferguson S, Harkins D, et al. Circulating tumor cells: clinically relevant molecular access based on a novel CTC flow cell. PLOS ONE. 2014;9(1):e86717.

46. Ueno Y, Furukawa K, Matsuo K, Inoue S, Hayashi K, Hibino H. On-chip graphene oxide aptasensor for multiple protein detection. Anal Chim Acta. 2015;866:1-9.

47. Stott SL, Hsu CH, Tsukrov DI, Yu M, Miyamoto DT, Waltman BA, et al. Isolation of circulating tumor cells using a microvortex-generating herringbone-chip. Proc Natl Acad Sci USA. 2010;107(43):18392-7.

48. Sheng W, Ogunwobi OO, Chen T, Zhang J, George TJ, Liu C, et al. Capture, release and culture of circulating tumor cells from pancreatic cancer patients using an enhanced mixing chip. Lab Chip. 2014;14(1):89-98.

49. Huang $T, X u$ C, Xiao J, Wang Q, Wang Y, Zhang Y, et al. Determination of the optimal detection time of circulating tumor cells for the postoperative monitoring of colorectal cancer. Oncol Lett. 2020;19(4):2996-3002.

50. Munugalavadla V, Mariathasan S, Slaga D, Du C, Berry L, Del Rosario G, et al. The PI3K inhibitor GDC-0941 combines with existing clinical regimens for superior activity in multiple myeloma. Oncogene. 2014;33(3):316-25.

51. Lapin M, Tjensvoll K, Oltedal S, Buhl T, Gilje B, Smaaland R, et al. MINDEC - an enhanced negative depletion strategy for circulating tumour cell enrichment. Sci Rep. 2016;6:28929.

52. Wang X, Sun L, Zhang H, Wei L, Qu W, Zeng Z, et al. Microfluidic chip combined with magnetic-activated cell sorting technology for tumor antigen-independent sorting of circulating hepatocellular carcinoma cells. PeerJ. 2019;7:e6681.

53. Vishnoi M, Peddibhotla S, Yin W, Scamardo AT, George GC, Hong DS, et al. The isolation and characterization of CTC subsets related to breast cancer dormancy. Sci Rep. 2015:5:17533.

54. Kallergi G, Politaki E, Alkahtani S, Stournaras C, Georgoulias V. Evaluation of isolation methods for circulating tumor cells (CTCS). Cell Physiol Biochem. 2016:40(3-4):411-9.

55. Karabacak NM, Spuhler PS, Fachin F, Lim EJ, Pai V, Ozkumur E, et al. Microfluidic, marker-free isolation of circulating tumor cells from blood samples. Nat Protoc. 2014;9(3):694-710.

56. Sharma S, Zhuang R, Long M, Pavlovic M, Kang Y, Ilyas A, et al. Circulating tumor cell isolation, culture, and downstream molecular analysis. Biotechnol Adv. 2018;36(4):1063-78.

57. Galletti G, Sung MS, Vahdat LT, Shah MA, Santana SM, Altavilla G, et al. Isolation of breast cancer and gastric cancer circulating tumor cells by use of an anti HER2-based microfluidic device. Lab Chip. 2014;14(1):147-56.

58. Wu Y, Deighan CJ, Miller BL, Balasubramanian P, Lustberg MB, Zborowski M, et al. Isolation and analysis of rare cells in the blood of cancer patients using a negative depletion methodology. Methods. 2013;64(2):169-82.

59. Werner SL, Graf RP, Landers M, Valenta DT, Schroeder M, Greene SB, et al. Analytical validation and capabilities of the Epic CTC Platform: enrichment-free circulating tumour cell detection and characterization. J Circ Biomark. 2015;4:3

60. Dawson SJ, Tsui DW, Murtaza M, Biggs H, Rueda OM, Chin SF, et al. Analysis of circulating tumor DNA to monitor metastatic breast cancer. N Engl J Med. 2013;368(13):1199-209.

61. Andreopoulou E, Yang LY, Rangel KM, Reuben JM, Hsu L, Krishnamurthy $S$, et al. Comparison of assay methods for detection of circulating tumor cells in metastatic breast cancer: adnaGen AdnaTest BreastCancer Select/Detect versus Veridex Cell Search system. Int J Cancer. 2012;130(7):1590-7.

62. Ferreira MM, Ramani VC, Jeffrey SS. Circulating tumor cell technologies. Mol Oncol. 2016;10(3):374-94.

63. Vona G, Sabile A, Louha M, Sitruk V, Romana S, Schutze K, et al. Isolation by size of epithelial tumor cells: a new method for the immunomorphological and molecular characterization of circulatingtumor cells. Am J Pathol. 2000;156(1):57-63. 
64. Hiltermann TJ, Pore MM, van den Berg A, Timens W, Boezen HM, Liesker $\mathrm{J}$, et al. Circulating tumor cells in small-cell lung cancer: a predictive and prognostic factor. Ann Oncol. 2012;23(11):2937-42.

65. Krebs MG, Sloane R, Priest L, Lancashire L, Hou JM, Greystoke A, et al. Evaluation and prognostic significance of circulating tumor cells in patients with non-small-cell lung cancer. J Clin Oncol. 2011;29(12):1556-63.

66. Hvichia GE, Parveen Z, Wagner C, Janning M, Quidde J, Stein A, et al. A novel microfluidic platform for size and deformability based separation and the subsequent molecular characterization of viable circulating tumor cells. Int J Cancer. 2016;138(12):2894-904.

67. Harouaka RA, Zhou MD, Yeh YT, Khan WJ, Das A, Liu X, et al. Flexible micro spring array device for high-throughput enrichment of viable circulating tumor cells. Clin Chem. 2014;60(2):323-33.

68. Ao Z, Liu X. Fiber-Optic Array Scanning Technology (FAST) for detection and molecular characterization of circulating tumor cells. Methods Mol Biol. 2017;1634:235-46.

69. Eliasova P, Pinkas M, Kolostova K, Gurlich R, Bobek V. Circulating tumor cells in different stages of colorectal cancer. Folia Histochem Cytobiol. 2017:55(1):1-5.

70. Ribeiro-Samy S, Oliveira MI, Pereira-Veiga T, Muinelo-Romay L, Carvalho S, Gaspar J, et al. Fast and efficient microfluidic cell filter for isolation of circulating tumor cells from unprocessed whole blood of colorectal cancer patients. Sci Rep. 2019;9(1):8032.

71. Harouaka RA, Nisic M, Zheng SY. Circulating tumor cell enrichment based on physical properties. J Lab Autom. 2013;18(6):455-68.

72. Banko P, Lee SY, Nagygyorgy V, Zrinyi M, Chae CH, Cho DH, et al. Technologies for circulating tumor cell separation from whole blood. J Hematol Oncol. 2019:12(1):48.

73. Gascoyne PR, Shim S. Isolation of circulating tumor cells by dielectrophoresis. Cancers. 2014;6(1):545-79.

74. Waheed W, Alazzam A, Mathew B, Christoforou N, Abu-Nada E. Lateral fluid flow fractionation using dielectrophoresis (LFFF-DEP) for size-independent, label-free isolation of circulating tumor cells. J Chromatogr B. 2018;1087-1088:133-7.

75. Alix-Panabieres C, Vendrell JP, Pelle O, Rebillard X, Riethdorf S, Muller V, et al. Detection and characterization of putative metastatic precursor cells in cancer patients. Clin Chem. 2007;53(3):537-9.

76. Lim J, Choi M, Lee H, Kim YH, Han JY, Lee ES, et al. Direct isolation and characterization of circulating exosomes from biological samples using magnetic nanowires. J Nanobiotechnol. 2019;17(1):1.

77. Mol EA, Goumans MJ, Doevendans PA, Sluijter JPG, Vader P. Higher functionality of extracellular vesicles isolated using size-exclusion chromatography compared to ultracentrifugation. Nanomed Nanotechnol Biol Med. 2017;13(6):2061-5

78. Li A, Zhang T, Zheng M, Liu Y, Chen Z. Exosomal proteins as potential markers of tumor diagnosis. J Hematol Oncol. 2017;10(1):175.

79. Yang D, Zhang W, Zhang H, Zhang F, Chen L, Ma L, et al. Progress, opportunity, and perspective on exosome isolation-efforts for efficient exosome-based theranostics. Theranostics. 2020;10(8):3684-707.

80. Soares Martins T, Catita J, Martins Rosa I, da AB Cruz e Silva O, Henriques AG. Exosome isolation from distinct biofluids using precipitation and column-based approaches. PLoS ONE. 2018;13(6):e0198820.

81. Zarovni N, Corrado A, Guazzi P, Zocco D, Lari E, Radano G, et al. Integrated isolation and quantitative analysis of exosome shuttled proteins and nucleic acids using immunocapture approaches. Methods. 2015:87:46-58.

82. Nakai W, Yoshida T, Diez D, Miyatake Y, Nishibu T, Imawaka N, et al. A novel affinity-based method for the isolation of highly purified extracellular vesicles. Sci Rep. 2016:6:33935.

83. Shrirao AB, Fritz Z, Novik EM, Yarmush GM, Schloss RS, Zahn JD, et al. Microfluidic flow cytometry: the role of microfabrication methodologies, performance and functional specification. Technology. 2018;6(1):1-23.

84. Zhang Z, Wang C, Li T, Liu Z, Li L. Comparison of ultracentrifugation and density gradient separation methods for isolating Tca8113 human tongue cancer cell line-derived exosomes. Oncol Lett. 2014;8(4):1701-6.

85. Skottvoll FS, Berg HE, Bjorseth K, Lund K, Roos N, Bekhradnia S, et al. Ultracentrifugation versus kit exosome isolation: nanoLC-MS and other tools reveal similar performance biomarkers, but also contaminations. Future Sci OA. 2019;5(1):FSO359.

86. Greening DW, Xu R, Ji H, Tauro BJ, Simpson RJ. A protocol for exosome isolation and characterization: evaluation of ultracentrifugation, density-gradient separation, and immunoaffinity capture methods. Methods Mol Biol. 2015;1295:179-209.

87. Thery C, Amigorena S, Raposo G, Clayton A. Isolation and characterization of exosomes from cell culture supernatants and biological fluids. Curr Protoc Cell Biol. 2006;30:3-22.

88. Gupta S, Rawat S, Arora V, Kottarath SK, Dinda AK, Vaishnav PK, et al. An improvised one-step sucrose cushion ultracentrifugation method for exosome isolation from culture supernatants of mesenchymal stem cells. Stem Cell Res Therapy. 2018;9(1):180.

89. Lobb R, Moller A. Size exclusion chromatography: a simple and reliable method for exosome purification. Methods Mol Biol. 2017;1660:105-10

90. Lim J, Choi M, Lee H, Han JY, Cho Y. A novel multifunctional nanowire platform for highly efficient isolation and analysis of circulating tumorspecific markers. Front Chem. 2018;6:664.

91. Tang YT, Huang YY, Zheng L, Qin SH, Xu XP, An TX, et al. Comparison of isolation methods of exosomes and exosomal RNA from cell culture medium and serum. Int J Mol Med. 2017;40(3):834-44.

92. Ding M, Wang C, Lu X, Zhang C, Zhou Z, Chen X, et al. Comparison of commercial exosome isolation kits for circulating exosomal microRNA profiling. Anal Bioanal Chem. 2018;410(16):3805-14.

93. Patel GK, Khan MA, Zubair H, Srivastava SK, Khushman M, Singh S, et al. Comparative analysis of exosome isolation methods using culture supernatant for optimum yield, purity and downstream applications. Sci Rep. 2019;9(1):5335.

94. Jiang Y, Shi M, Liu Y, Wan S, Cui C, Zhang L, et al. Aptamer/AuNP biosensor for colorimetric profiling of exosomal proteins. Angew Chem. 2017:56(39):11916-20.

95. Burt R. Inheritance of Colorectal Cancer. Drug Discov Today Dis Mech. 2007:4(4):293-300.

96. Barnetson RA, Tenesa A, Farrington SM, Nicholl ID, Cetnarskyj R, Porteous ME, et al. Identification and survival of carriers of mutations in DNA mismatch-repair genes in colon cancer. N Engl J Med. 2006;354(26):2751-63.

97. Burz C, Pop VV, Buiga R, Daniel S, Samasca G, Aldea C, et al. Circulating tumor cells in clinical research and monitoring patients with colorectal cancer. Oncotarget. 2018;9(36):24561-71.

98. Bork U, Rahbari NN, Scholch S, Reissfelder C, Kahlert C, Buchler MW, et al. Circulating tumour cells and outcome in non-metastatic colorectal cancer: a prospective study. Br J Cancer. 2015;112(8):1306-13.

99. Sanders MA, Majumdar AP. Colon cancer stem cells: implications in carcinogenesis. Front Biosci. 2011;16:1651-62.

100. Fanali C, Lucchetti D, Farina M, Corbi M, Cufino V, Cittadini A, et al. Cancer stem cells in colorectal cancer from pathogenesis to therapy: controversies and perspectives. World J Gastroenterol. 2014;20(4):923-42.

101. Li CJ, Zhang X, Fan GW. Updates in colorectal cancer stem cell research. J Cancer Res Therap. 2014;10(Suppl):233-9.

102. Matsumura T, Sugimachi K, linuma H, Takahashi Y, Kurashige J, Sawada $G$, et al. Exosomal microRNA in serum is a novel biomarker of recurrence in human colorectal cancer. Br J Cancer. 2015;113(2):275-81.

103. Manri C, Yokoi T, Nishida H. Size-selective harvesting of extracellular vesicles for strategic analyses towards tumor diagnoses. Appl Biochem Biotechnol. 2017;182(2):609-23.

104. Rappa G, Mercapide J, Anzanello F, Pope RM, Lorico A. Biochemical and biological characterization of exosomes containing prominin-1/CD133. Mol Cancer. 2013;12:62.

105. Demory Beckler M, Higginbotham JN, Franklin JL, Ham AJ, Halvey PJ, Imasuen IE, et al. Proteomic analysis of exosomes from mutant KRAS colon cancer cells identifies intercellular transfer of mutant KRAS. Mol Cell Proteomics. 2013;12(2):343-55.

106. Chiba M, Kimura M, Asari S. Exosomes secreted from human colorectal cancer cell lines contain mRNAs, microRNAs and natural antisense RNAs, that can transfer into the human hepatoma HepG2 and lung cancer A549 cell lines. Oncol Rep. 2012;28(5):1551-8.

107. Norcic G. Liquid biopsy in colorectal cancer-current status and potential clinical applications. Micromachines. 2018;9(6):300.

108. Ma B, King AD, Leung L, Wang K, Poon A, Ho WM, et al. Identifying an early indicator of drug efficacy in patients with metastatic colorectal 
cancer-a prospective evaluation of circulating tumor cells, 18F-fluorodeoxyglucose positron-emission tomography and the RECIST criteria. Ann Oncol. 2017;28(7):1576-81.

109. Cohen SJ, Punt CJ, lannotti N, Saidman BH, Sabbath KD, Gabrail NY, et al. Relationship of circulating tumor cells to tumor response, progressionfree survival, and overall survival in patients with metastatic colorectal cancer. J Clin Oncol. 2008;26(19):3213-21.

110. Cristofanilli M, Pierga JY, Reuben J, Rademaker A, Davis AA, Peeters DJ, et al. The clinical use of circulating tumor cells (CTCS) enumeration for staging of metastatic breast cancer (MBC): international expert consensus paper. Crit Rev Oncol Hematol. 2019;134:39-45.

111. Li J, Fu W, Zhang W, Li P. High number of circulating tumor cells predicts poor survival of cutaneous melanoma patients in China. Med Sci Monit. 2018;24:324-31.

112. Gallagher DJ, Milowsky MI, Ishill N, Trout A, Boyle MG, Riches J, et al. Detection of circulating tumor cells in patients with urothelial cancer. Ann Oncol. 2009;20(2):305-8.

113. Jia S, Zhang R, Li Z, Li J. Clinical and biological significance of circulating tumor cells, circulating tumor DNA, and exosomes as biomarkers in colorectal cancer. Oncotarget. 2017:8(33):55632-45.

114. Allen JE, Saroya BS, Kunkel M, Dicker DT, Das A, Peters KL, et al. Apoptotic circulating tumor cells (CTCs) in the peripheral blood of metastatic colorectal cancer patients are associated with liver metastasis but not CTCs. Oncotarget. 2014;5(7):1753-60.

115. Hou JM, Krebs MG, Lancashire L, Sloane R, Backen A, Swain RK, et al. Clinical significance and molecular characteristics of circulating tumor cells and circulating tumor microemboli in patients with small-cell lung cancer. J Clin Oncol. 2012;30(5):525-32.

116. Shahabipour F, Barati N, Johnston TP, Derosa G, Maffioli P, Sahebkar A. Exosomes: nanoparticulate tools for RNA interference and drug delivery. J Cell Physiol. 2017:232(7):1660-8.

117. Fan WTX, Huang E, Zhang JJ. Exosomes from CIITA-transfected CT26 cells enhance antitumor effects. Asian Pac J Cancer Prev. 2013;14(2):987-91.

118. Harada T, Yamamoto H, Kishida S, Kishida M, Awada C, Takao T, et al. Wnt5b-associated exosomes promote cancer cell migration and proliferation. Cancer Sci. 2017;108(1):42-52.

119. Silva J, Garcia V, Rodriguez M, Compte M, Cisneros E, Veguillas P, et al. Analysis of exosome release and its prognostic value in human colorectal cancer. Genes Chromosomes Cancer. 2012;51(4):409-18.

120. Soldevilla B, Rodriguez M, San Millan C, Garcia V, Fernandez-Perianez $\mathrm{R}$, Gil-Calderon B, et al. Tumor-derived exosomes are enriched in DeltaNp73, which promotes oncogenic potential in acceptor cells and correlates with patient survival. Hum Mol Genet. 2014;23(2):467-78.

121. Ji H, Chen M, Greening DW, He W, Rai A, Zhang W, et al. Deep sequencing of RNA from three different extracellular vesicle (EV) subtypes released from the human LIM1863 colon cancer cell line uncovers distinct miRNA-enrichment signatures. PLOS ONE. 2014;9(10):e110314.

122. Lim JW, Mathias RA, Kapp EA, Layton MJ, Faux MC, Burgess AW, et al. Restoration of full-length APC protein in SW480 colon cancer cells induces exosome-mediated secretion of DKK-4. Electrophoresis. 2012;33(12):1873-80.

123. Hu Y, Yan C, Mu L, Huang K, Li X, Tao D, et al. Fibroblast-derived exosomes contribute to chemoresistance through priming cancer stem cells in colorectal cancer. PLoS ONE. 2015;10(5):e0125625.

124. Wang MSZ, Amoah Barnie P. Crosstalk among colon cancer-derived exosomes, fibroblast-derived exosomes, and macrophage phenotypes in colon cancer metastasis. Int Immunopharmacol. 2020;81:106298.

125. Ji H, Greening DW, Barnes TW, Lim JW, Tauro BJ, Rai A, et al. Proteome profiling of exosomes derived from human primary and metastatic colorectal cancer cells reveal differential expression of key metastatic factors and signal transduction components. Proteomics. 2013;13(10-11):1672-86.

126. Huang H, Zheng X, Cai C, Yao Z, Lu S, Meng X, et al. Exosomes derived from breast cancer lung metastasis subpopulations promote tumor self-seeding. Biochem Biophys Res Commun. 2018:503(1):242-8.

127. Maia J, Caja S, Strano Moraes MC, Couto N, Costa-Silva B. Exosomebased cell-cell communication in the tumor microenvironment. Front Cell Dev Biol. 2018;6:18.
128. Luga V, Zhang L, Viloria-Petit AM, Ogunjimi AA, Inanlou MR, Chiu E, et al. Exosomes mediate stromal mobilization of autocrine Wnt-PCP signaling in breast cancer cell migration. Cell. 2012;151(7):1542-56.

129. Baig MSRA, Rajpoot S, Liu D, Savai R, Banerjee S, Kawada M, Faisal SM, Saluja R, Saqib U, Ohishi T, Wary KK. Tumor-derived exosomes in the regulation of macrophage polarization. Inflamm Res. 2020;69(5):435-51.

130. Takano Y, Masuda T, linuma H, Yamaguchi R, Sato K, Tobo T, et al. Circulating exosomal microRNA-203 is associated with metastasis possibly via inducing tumor-associated macrophages in colorectal cancer. Oncotarget. 2017:8(45):78598-613.

131. Cha DJ, Franklin JL, Dou Y, Liu Q, Higginbotham JN, Demory Beckler M, et al. KRAS-dependent sorting of miRNA to exosomes. eLife. 2015:4:e07197.

132. Lan J, Sun L, Xu F, Liu L, Hu F, Song D, et al. M2 macrophage-derived exosomes promote cell migration and invasion in colon cancer. Cancer Res. 2019;79(1):146-58.

133. Parolini I, Federici C, Raggi C, Lugini L, Palleschi S, De Milito A, et al. Microenvironmental $\mathrm{pH}$ is a key factor for exosome traffic in tumor cells. J Biol Chem. 2009;284(49):34211-22.

134. Cossetti C, Iraci N, Mercer TR, Leonardi T, Alpi E, Drago D, et al. Extracellular vesicles from neural stem cells transfer IFN-gamma via Ifngr1 to activate Stat1 signaling in target cells. Mol Cell. 2014;56(2):193-204.

135. Shackleton M, Quintana E, Fearon ER, Morrison SJ. Heterogeneity in cancer: cancer stem cells versus clonal evolution. Cell. 2009;138(5):822-9.

136. Ciardiello C, Cavallini L, Spinelli C, Yang J, Reis-Sobreiro M, de Candia P, et al. Focus on extracellular vesicles: new frontiers of cell-to-cell communication in cancer. Int J Mol Sci. 2016;17(2):175.

137. Hwang WL, Lan HY, Cheng WC, Huang SC, Yang MH. Tumor stem-like cell-derived exosomal RNAs prime neutrophils for facilitating tumorigenesis of colon cancer. J Hematol Oncol. 2019;12(1):10.

138. Shang AGC, Zhou C, Yang Y, Chen C, Zeng B, Wu J, Lu W, Wang W, Sun $Z$, Li D. Exosomal KRAS mutation promotes the formation of tumorassociated neutrophil extracellular traps and causes deterioration of colorectal cancer by inducing IL-8 expression. Cell Commun Signal. 2020;18(1):52

139. Lindoso RS, Collino F, Vieyra A. Extracellular vesicles as regulators of tumor fate: crosstalk among cancer stem cells, tumor cells and mesenchymal stem cells. Stem Cell Investig. 2017;4:75.

140. Kumar D, Gupta D, Shankar S, Srivastava RK. Biomolecular characterization of exosomes released from cancer stem cells: possible implications for biomarker and treatment of cancer. Oncotarget. 2015;6(5):3280-91.

141. Grange C, Brossa A, Bussolati B. Extracellular vesicles and carried miRNAs in the progression of renal cell carcinoma. Int J Mol Sci. 2019;20(8):1832.

142. Lopatina T, Gai C, Deregibus MC, Kholia S, Camussi G. Cross talk between cancer and mesenchymal stem cells through extracellular vesicles carrying nucleic acids. Front Oncol. 2016;6:125.

143. Que ZJLB, Wang CT, Qian FF, Jiang Y, Li Y, Han XH, Li HG, Liu JX, Tian $J$ H. Proteomics analysis of tumor exosomes reveals vital pathways of Jinfukang inhibiting circulating tumor cells metastasis in lung cancer. J Ethnopharmacol. 2020;256:112802.

144. Nanou AMM, Zeune LL, de Wit S, Punt CJA, Groen HJM, Hayes DF, de Bono JS, Terstappen LWMM. Tumour-derived extracellular vesicles in blood of metastatic cancer patients associate with overall survival. $\mathrm{Br} J$ Cancer. 2020;122(6):801-11.

145. Chen J, Li J, Sun Y. Microfluidic approaches for cancer cell detection, characterization, and separation. Lab Chip. 2012;12(10):1753-67.

146. Kolodziejczyk AA, Kim JK, Svensson V, Marioni JC, Teichmann SA. The technology and biology of single-cell RNA sequencing. Mol Cell. 2015;58(4):610-20.

147. Hood L. Systems biology and p4 medicine: past, present, and future. Rambam Maimonides Med J. 2013;4(2):e0012.

\section{Publisher's Note}

Springer Nature remains neutral with regard to jurisdictional claims in published maps and institutional affiliations. 